\title{
Mental Imagery and Affect in English/French Bilingual Readers: A Cross-Linguistic Perspective
}

\author{
Karen A. Krasny \\ Mark Sadoski
}

\begin{abstract}
We investigated the evocation of mental imagery and affect in English/French bilinguals to determine whether the linguistic demands of reading in a second language (L2) limit readers' ability to form non-verbal text representations of literary stories. The participants were 26 Grade 11 French immersion students enrolled in a Canadian high school. Each student read two literary stories, one in English and another in French. Next they rated story paragraphs for the degree of either mental imagery or emotional response evoked. Later, students reread the same texts and completed a writing task in which they reported their imagery or emotions in response to the two highest-rated paragraphs. Moderate to high correlations were found between ratings of imagery and emotional response for each story, for two French stories combined, for two English stories combined, and for all stories in both languages combined. Reading times were somewhat longer for the French versions. The patterns of response for both the ratings and the written reports replicate and extend earlier research and suggest that as bilingual readers progress in their ability to read in their L2, reports of imagery and affect become closer in kind and number to those reported in response to reading the same text in their first language.
\end{abstract}

Keywords: mental imagery, affect, bilingual reading, French, English

Résumé : Nous avons étudié l'évocation d'images mentales et les réactions affectives auprès de bilingues anglais-français, afin de déterminer si les exigences langagières de la lecture en langue seconde (L2) restreignent l'habileté des lecteurs à se former des représentations non verbales de textes littéraires. L'étude regroupait 26 élèves d'immersion française en $11^{\mathrm{e}}$ année dans une école secondaire canadienne. Chaque élève a lu deux textes littéraires, l'un en anglais et l'autre en français. Ils ont ensuite évalué dans quelle mesure chaque paragraphe des histoires avait suscité en eux soit des images soit des émotions. Par la suite, les participants ont relu ces mêmes textes, puis ils ont documenté par écrit les images ou les réactions affectives qu'avaient suscitées en eux les deux paragraphes qu'ils avaient jugés les plus évocateurs. Nous avons trouvé des corrélations modérées à fortes entre les images et les réactions affectives rapportées pour chaque histoire, pour deux 
histoires en français combinées, pour deux histoires en anglais combinées, et pour toutes les histoires dans les deux langues combinées. Le temps exigé par la lecture s'est révélé un peu plus long pour les versions françaises.

Les tendances dans les réponses - pour les évaluations tout comme pour les rapports écrits - sont comparables aux constatations antérieures et apportent un complément d'information. Les résultats de la présente étude suggèrent que, plus leurs habiletés de lecture en L2 se développent, plus les lecteurs bilingues rapportent des types et un nombre d'images et de réactions affectives qui se rapprochent de celles que suscite chez eux la lecture du même texte dans leur langue maternelle.

Mots clés : imagerie mentale, réactions affectives, lecture bilingue, français, anglais

\section{Introduction}

Decades of research support the contention that the evocation of mental imagery and affect during reading contributes to the comprehension, recall, and appreciation of texts across a range of genres (e.g., Gambrell, 1982; Gambrell \& Bales, 1986; Gambrell \& Jawitz, 1993; Long, Winograd \& Bridge, 1989; Pressley, 1976; Sadoski, Goetz, \& Kangiser, 1988; Sadoski, Goetz, \& Rodriguez, 2000). Imaginative and affective responses to literature are central to continuing debates about the nature of reader response. Presently, we are witnessing a renewed interest in the sensory or 'embodied' basis for thought (e.g., Damasio, 1999, 2003; Johnson, 1993; Kosslyn, 1994; Lakoff \& Johnson, 1999; Nussbaum, 2001; Paivio, 1971, 1986, 1991). Consequently, in the field of reading, we are challenged to explore anew how the realm of sensuous cognition contributes to our capacity for making meaning from, and responding to, literary texts.

Theoretical and empirical studies investigating reader response have found that the relationship between mental imagery and affect is central to 'lived through' experience and mental modelling of literature (Sadoski et al., 1988; Rosenblatt, 1994). But whereas a number of studies have shown how one's cultural background affects reading comprehension (e.g., Anderson, Reynolds, Schallert, \& Goetz, 1977; Goetz, Schallert, Reynolds, \& Radin, 1983; Kintsch \& Green, 1978; Pritchard, 1990; Reynolds, Taylor, Steffensen, Shirey, \& Anderson, 1982), very few studies have investigated the extent to which reading in a second language (L2) might affect the degree of mental imagery and affect evoked in stories that are culturally relevant. 
In the present study, we investigated imagery and affect reported by English/French bilingual readers from the perspective of dual coding theory (Paivio, 1971, 1986, 1991, 2007; Sadoski \& Paivio, 2001, 2004). Dual coding theory (DCT) assumes that meaning depends on the activity of two separate but interconnected mental coding systems, one specialized for the representation and processing of language and the other specialized for the representation and processing of nonverbal objects and events, including imagery and affect. This theory asserts that our mental representations retain some of the concrete qualities of the sensory experiences that formed them and that, therefore, representational structures and processes have a sensory, 'embodied' basis. We experience and encode visual language in reading, but we also experience and encode non-verbal visual stimuli, such as common objects and scenes from our daily life. Likewise, we experience and encode oral language in listening to speech, but we also experience and encode common environmental sounds that are not speech. We also form mental connections among all these.

For example, imagine the rich associations that might be evoked by the simple phrase breakfast at a roadside diner. One can imagine a steaming cup of coffee, set upon a paper placemat, atop a shiny arborite tabletop, flanked by red vinyl seating. The aroma of fresh coffee mingles with the sound and smell of sizzling bacon and the noises of the comings and goings of waitresses and customers. The images and language evoked by the original phrase can produce an elaborate mental model of its meaning. Affective responses might occur as well. DCT assumes that as we read for meaning, we are constantly activating such representations and the connections between them, even if we are not consciously aware of them all. The extent of such activity depends on both text characteristics (e.g., language concreteness) and individual differences in readers (e.g., prior knowledge).

DCT has been extended to account for bilingualism. In their model of a bilingual mind, Paivio and Desrochers (1980) propose that bilinguals maintain two verbal systems that function independently, in connection with each other (i.e., translation), or in connection with a common non-verbal collection of images. For example, the English word bread can be translated to the French word pain. Both words may evoke a common image, but this depends somewhat on cultural experience. In much of the United States and Canada, bread is typically a short, sliced loaf purchased at a supermarket; in France, however, bread is often a long, unsliced loaf purchased at a bakery. The different cultural associations of bread and pain might evoke the 
same image or different images as the referent, depending on the cultural experiences of the reader (Paivio, 1986). Research on the linguistic interdependence principle (Cummins, 1979; Cummins \& Swain, 1986; Genesee, 1987; Krashen \& Biber, 1988) has also attempted to account for the transfer of cognitive and literacy-related skills across languages. These theories generally support the idea that bilingual instruction enhances metalinguistic skills. Our investigation sought to explore the implication that bilingual readers are able to access both verbal and non-verbal sources of information while reading texts in either L1 or L2.

The relationship of imagery to affect and emotional response has also been theorized and empirically supported. Goetz and Sadoski (1996) reviewed a systematic 10-year program of research into the way imagery is related to emotional response in reading literary stories. This program of studies found that imagery and emotional response were moderately to strongly correlated in literary reading and that both were related to overall story comprehension and appreciation. Two decades ago, Alderson (1984) opened the debate over whether problems in L2 reading were grounded in reading problems or in language problems. In their review of subsequent studies (Bossers, 1991; Brisbois, 1995; Carrell, 1991; Hacquebord, 1989; Roller, 1988) that potentially addressed Alderson's questions, Bernhardt and Kamil (1995) conclude that while studies' findings point to the dominance of the L1 reading variable, the range of estimates does not fully resolve the question. In a study of 186 English speakers reading English and Spanish, these authors found that language proficiency accounted significantly for more than $30 \%$ of the variance in L2 reading scores and that L1 reading accounted for more than $10 \%$ of the variance. They concluded that it is not an either/or question, as initially posed by Alderson. Several studies (Fecteau, 1999; Lee \& Lemonnier-Schallert, 1997; Pichette, 1995; Taillefer, 1996; Wagner, Spratt, \& Ezzaki, 1989) have supported Bernhardt and Kamil's conclusion that both variables contribute significantly to the L2 reading process and that no single variable can account entirely for problems in L2 reading. Alderson (1984) has suggested that the varying influence of both factors documented by the range of studies might be accounted for by Clarke's (1980) language threshold hypothesis.

Clarke (1980) attempts to extend Cummins' (1979) linguistic interdependence hypothesis in one significant way, theorizing that readers must achieve a threshold of L2 knowledge in order to transfer their reading skills effectively from L1 to L2. Clarke's language threshold hypothesis remains a vague construct, insofar as there is no clear 
psychological accounting for how and when L2 learners actually achieve this threshold. While the language threshold hypothesis is typically associated with beginning L2 learners, we have observed that despite considerable time spent reading French materials, both literary and expository, French immersion students in the senior years continue to rely heavily on French and French/English dictionaries when they encounter unknown words. This would indicate that perhaps even more advanced immersion students are limited in their ability to access and apply a range of reading-comprehension strategies, including the active formation of mental imagery in response to text. We were interested in knowing whether the French immersion students in this study had achieved the level of linguistic competence necessary to use mental imagery as a strategy for comprehending texts written in their L2 or whether the linguistic demands of reading in a second language compromised their capacity to form non-verbal representations. In other words, were the L2 readers in this study, when reading texts in their L2, more apt to read simply to get to the bottom of the page, or were they able to form mental imagery and evaluate their emotional responses in order to achieve more inferential and critical levels of comprehension?

In this investigation, we examined the responses of Grade 11 students enrolled in a Canadian French immersion high school to two stories read in either English or French. The study replicates and extends the original study by Sadoski, Goetz, and Kangiser (1988) in English alone and a subsequent bilingual extension by Steffensen, Goetz, and Cheng (1999), who examined the responses of bilingual Chinese readers to a single text about a train trip presented in both languages. Specifically, the present study was intended to address the following research questions:

1 Is there a significant difference between the ratings for images and emotional responses by bilingual readers for the same text read in their first (English) and second (French) languages?

2 Do bilingual readers give similar responses in terms of the frequency and type of free reports of imagery and emotion evoked while reading in their first and second languages?

Any comparison between the present study and that of Steffensen et al. (1999) must take into consideration the educational, social, and political influences that shape the bilingual experience of study participants. From the Canadian perspective, the most obvious 
political distinction is that French and English share official-language status, which is to say that neither French nor English is considered a 'foreign language.' The right to access education in either of Canada's two official languages has been strongly endorsed by the Royal Commission on Bilingualism and Biculturalism (1970), which maintains that language creates a particular world-view. This position leads to the question of whether that world-view is significantly different in the participants' second official language than in their first. Are readers more able to form richer personal and cultural images while reading in their first language (L1) than while reading in their L2? Beyond the number and type of images evoked, does the language of the text affect the aesthetic and emotional quality of the reader's experience? An analysis of the quantitative and qualitative responses in this study offers an increased understanding of the nature of the experience associated with reading literary texts in a second language.

\section{Method}

\section{Participants}

The participants were 26 Grade 11 French Immersion students between the ages of 16 and 18 enrolled in a dual-track (English/ French) Canadian high school. All students were identified as 'early immersion,' meaning that they began French immersion in either kindergarten or Grade 1. Throughout their schooling, French has been the language of instruction for all core subjects and electives, with the exception of the prescribed hours of instruction in English language arts beginning in Grade 1. Fifteen participants were female, and 11 were male. All spoke English as their L1 and French as their L2. Context variables and variations in the implementation of French immersion programming across North America make it difficult to establish performance standards. Despite decades of Canadian and international research on French immersion, we know of no widely accepted, norm-referenced standardized test used to measure the French linguistic competency of immersion students at the senior level. The students in this study, however, all met or exceeded the Grade 10 curricular expectations for reading and writing in English Language Arts and Français set forth by the province, as demonstrated by district-wide examination results in the previous year. In accordance with the school district's policy, participation in the study was voluntary. 


\section{Materials}

Two short stories were used. The stories contain 1,500 words or fewer and are typical of those found in reading textbooks and literary anthologies used in secondary schools. In each story, a series of events rises to a climax and is immediately followed by a plot twist that brings the story to a surprise conclusion. The stories 'A Secret for Two' and 'Two Were Left' appear in The Best Short Shorts (Berger, 1958) and were chosen as two of the three stories used in the study by Sadoski et al. (1988). Story synopses appear in Figure 1. None of the participants reported having read either story before this study. For this investigation, the stories were also translated into French and titled 'Un secret pour deux' ('A Secret for Two') and 'Deux qui restaient' ('Two Were Left'); we retained the services of a professional translator who is regularly contracted by the province and by local school districts to translate curriculum and examination materials from English into French for use in French immersion elementary and secondary classrooms.

\section{FIGURE1}

Synopses of the two stories.

\section{'A Secret for Two' by Quentin Reynolds}

Pierre Dupin, a Montreal milkman, delivers milk over the same route for many years. A white horse named Joseph draws his milk wagon, and a close comradeship grows between the two. Joseph learns the route so well that he pulls the wagon to the appropriate street and stops at the appropriate houses with no directions from Pierre. Pierre, being illiterate, receives spoken orders from customers and reports these to his foreman; he often boasts that a blind man could do his route. Pierre and Joseph grow old together, and, on one particularly crystalline winter morning, Pierre arrives at work to learn that Joseph has died in the night. The foreman notices a dead, soulless look in Pierre's eyes, and Pierre suddenly turns and steps in front of an oncoming truck. He is killed instantly. An ambulance doctor reveals that Pierre's eyes had been completely blinded by cataracts for years. Pierre had kept this a secret from all but Joseph.

\section{'Two Were Left' by Hugh Cave}

Noni, an Inuit youth, and Nimuk, his lead husky, have been marooned on an ice floe after a break-up. After three days of hunger, it becomes obvious that, despite their comradeship, one will soon be forced to devour the other. Unarmed, Noni forges a knife by sharpening one small strip of metal against another during the night. In the morning, he calls the dog to him and prepares to strike, but cannot, and flings the knife away. It sticks in the ice some distance away and out of reach. Nimuk then instinctively circles the boy to attack, but is also incapable of killing his friend. He licks Noni's cheek, and the two weakly lie down to await starvation. Sometime later, a coastal patrol plane sees a flashing signal from the ice floe. The pilot finds the pair too weak to move. The signal had come from the crudely polished knife, stuck in the ice and quivering in the wind. 


\section{Procedure}

Each participant received a package of materials containing two copies of each of the two stories. Both copies of one story were written in English and both copies of the other story were written in French. The stories were counterbalanced in the order of language, so that each story in each language occurred equally often as the first story and as the second story.

As in the original study (Sadoski et al., 1988), a cover sheet was attached to the first copy of each story that instructed students to read the story as they would normally read for enjoyment and that no test would follow. Students were also required to record the time taken to read each story by filling in the blank 'Time:- - ' at the top of the first page of each story and again when they reached the bottom of the last page. On the second copy of each story, a numerical rating scale was printed in the margin to the right of each paragraph. On the cover page attached to the second copy of each story, students were given instructions for rating each paragraph for either imagery or emotional response. Half the students rated both stories for the imagery evoked; the other half rated both stories for emotional response. Students were randomly assigned to one of these rating types. The stories were also counterbalanced for language as much as possible, given that there were 26 participants and four possible story combinations assigned to one of two different rating types. Ideally, half of the participants $(n=13)$ would have read a particular story in English and the other half would have read the same story in French. In our study, 14 participants read story combinations that included 'A Secret for Two' and 'Deux qui restaient,' while 12 read story combinations that included 'Two Were Left' and 'Un secret pour deux.'

All instructions and the verbal cues for the ratings were given in English. Figure 2 shows the rating scales for imagery and emotional response. All tasks were completed within 30 minutes of a regular 45-minute class session. Students were not aware that other students were rating the stories for a different reason.

A preliminary analysis was performed to rank the paragraphs according to the mean ratings of imagery and emotional response evoked. The two top-ranking paragraphs for each story in each language were identified. Approximately four weeks after the initial rating session, the same students received a second package of materials containing copies of the two stories, each in the language and order in which they had read them before. Attached to the end of each story in this second package were additional pages that identified 
FIGURE 2

Rating scales for imagery and affect.

\section{Imagery}

Students rated each paragraph on the following scale:

1. No mental imagery associated with this paragraph.

2. Very weak imagery; barely perceptible.

3. Imagery that was a little stronger; but not too vivid or memorable.

4. Distinct imagery that was moderately vivid and memorable.

5 . Very vivid imagery that was strongly memorable.

\section{Affect}

Students rated each paragraph on the following scale:

1. No feelings evoked by this paragraph.

2. Slight feelings evoked by this paragraph.

3. Moderate feelings evoked by this paragraph.

4. Fairly strong feelings evoked by this paragraph.

5 . Very powerful feelings evoked by this paragraph.

the paragraphs ranked highest for either mental imagery or emotional response. Students received instructions to reread each story and complete the pages at the end. Depending on the rating type originally assigned, students were instructed to describe in their own words either the images they formed or the emotions they experienced while reading. They were allowed to write in either English or French. Students were able to reread the stories and complete the written responses well within a 45 -minute class session.

\section{Results}

\section{Quantitative ratings}

Overall means and standard deviations for paragraph ratings for each of the four story versions, 'A Secret for Two,' 'Un secret pour deux,' 'Two Were Left,' and 'Deux qui restaient,' are provided in Table 1. Graphic depictions of the levels of imagery and emotional response evoked for each story version are shown in Figures 3-6.

The overall patterns of response in Figures 3 through 6 reflect the rising action toward a climactic point near the very end of the story, followed by a plot twist leading to an abrupt surprise conclusion. In Figure 3, imagery ratings for 'A Secret for Two' are consistently high for paragraphs 2 through 5, which describe Pierre's daily regimen, his faithful horse, and their familiar route through the streets of Montreal. Major high points occur at paragraph 18, in which the 
TABLE1

Means and standard deviations for ratings by story

\begin{tabular}{|c|c|c|c|c|c|c|c|c|}
\hline \multirow[b]{3}{*}{ Story } & \multicolumn{8}{|c|}{ Ratings } \\
\hline & \multicolumn{3}{|c|}{ Imagery } & \multicolumn{3}{|c|}{ Affect } & \multicolumn{2}{|c|}{ Words per paragraph } \\
\hline & $M$ & $S D$ & $n$ & $M$ & $S D$ & $n$ & $M$ & $S D$ \\
\hline 'A Secret for Two' & 3.06 & 0.85 & 7 & 2.82 & 0.78 & 7 & 49.20 & 32.73 \\
\hline 'Un secret pour deux' & 3.31 & 0.66 & 6 & 2.84 & 1.04 & 6 & 51.43 & 33.69 \\
\hline 'Two Were Left' & 3.56 & 0.50 & 6 & 2.96 & 0.62 & 6 & 33.10 & 23.64 \\
\hline 'Deux qui restaient' & 3.15 & 0.79 & 7 & 2.51 & 0.68 & 7 & 38.00 & 26.71 \\
\hline
\end{tabular}

FIGURE 3

'A Secret for Two': Imagery and affect.

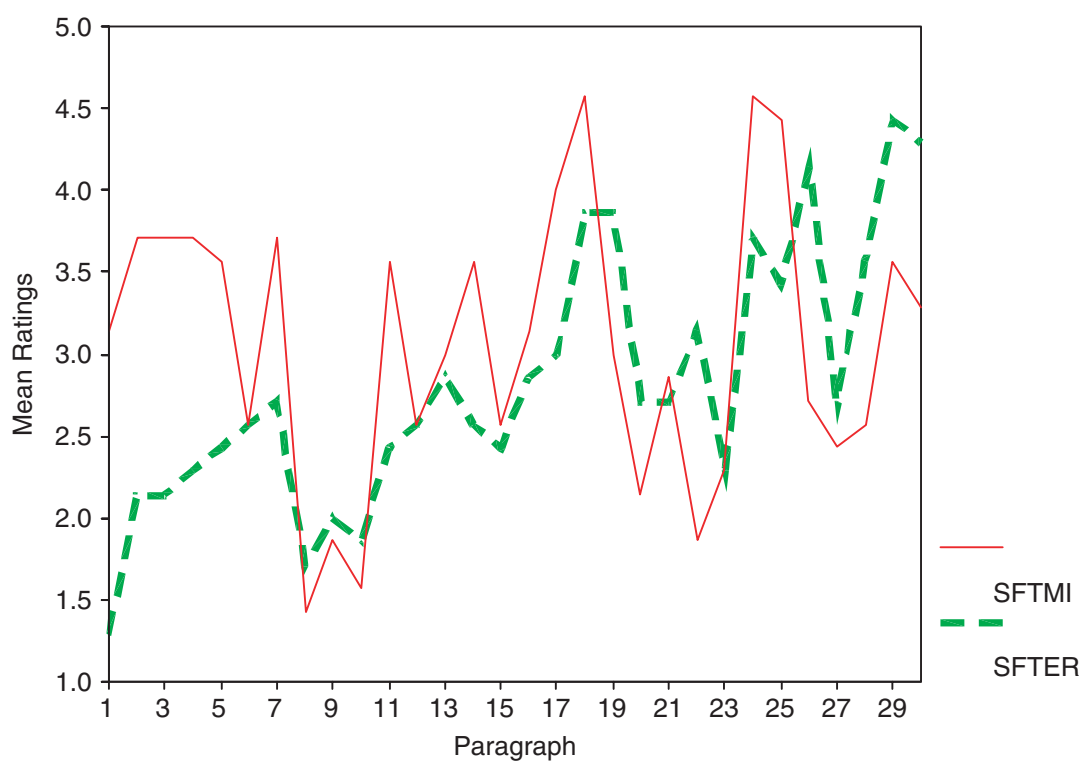

author likens the cold morning air to 'iced wine' and the newly fallen snow to 'a million glistening diamonds,' and at paragraph 24 , in which the grief-stricken look in Pierre's eyes holds the gaze of the stable foreman. The imagery rating remains high for paragraph 25 as Pierre, tears streaming down his face, walks into the path of an oncoming truck. A final high point in the imagery ratings occurs in paragraph 29, at the end of the story, as the ambulance doctor points out the cataracts that have blinded Pierre's eyes. The overall pattern of response and 
FIGURE 4

'Un secret pour deux': Imagery and affect.

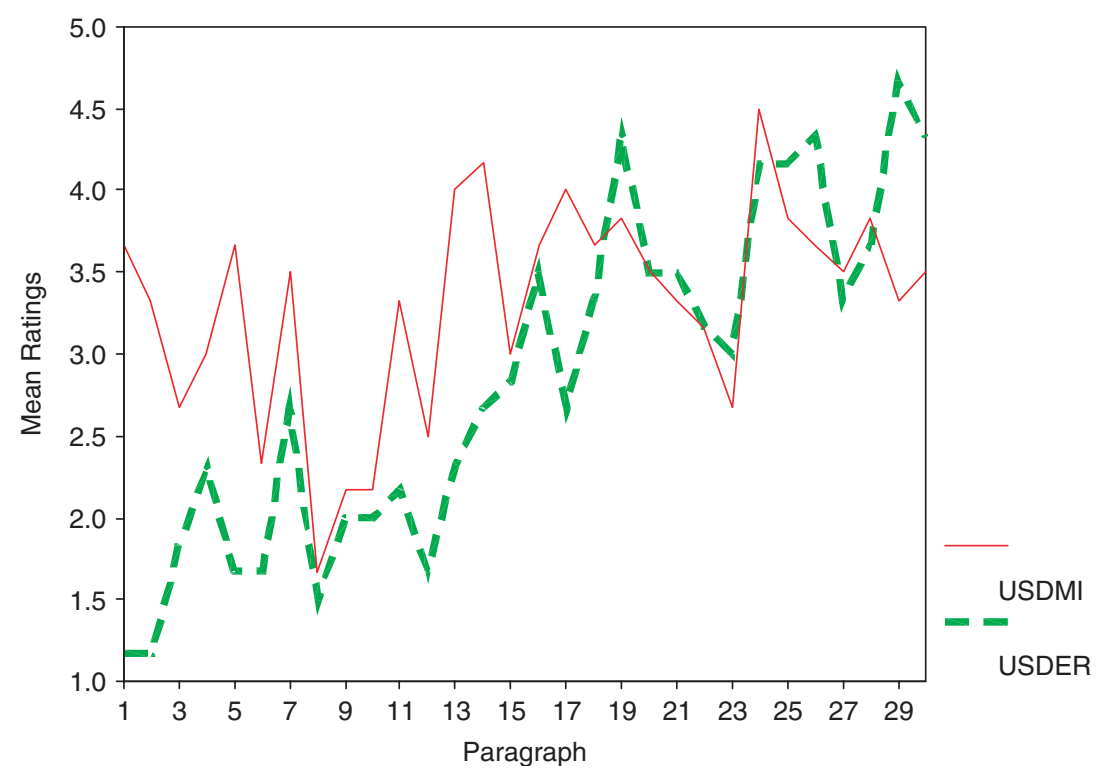

the high points are consistent with those identified in the original study.

Figure 4 depicts the imagery ratings for 'Un secret pour deux.' The patterns of imagery ratings appear generally similar for the English and French versions of the story. In the French version, the imagery ratings are high for paragraphs 1 and 2 but drop in paragraph 3, in which the physical description of the horse in paragraph 2 turns to Pierre's remarks about its character. Imagery ratings rise again for paragraphs 4 and 5, again corresponding to the ratings for the English version, 'A Secret for Two.' Major high points occur at paragraphs 13 and 14, which describes how Pierre relies on his memory to tell Jacques about the changes made to the deliveries to the various households, how Jacques records the details in a small notebook, and how Pierre goes about his work each morning. The next high point in 'Un secret pour deux' occurs at paragraph 17, rather than at paragraph 18 , as in the English version. In paragraph 17, the bond between Pierre and his horse, Joseph, is implied by the way they appear years younger as they work together but succumb to the look of old age when they part at the end of day. The imagery ratings remain high for 
FIGURE 5

'Two Were Left': Imagery and affect.

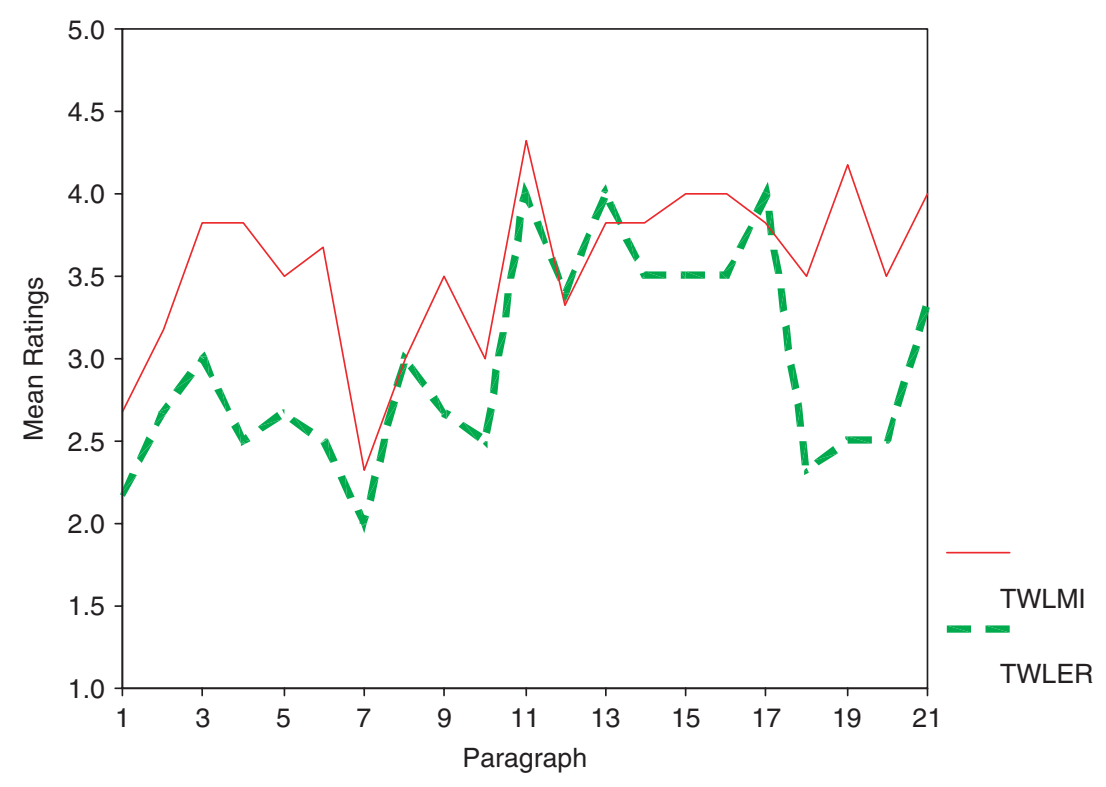

paragraph 18, described earlier as a high point in the English version, and for paragraph 19, in which Pierre learns of the death of his horse. As in the English version, the imagery ratings for the French version are also high for paragraphs 24 and 25, in which Pierre is overcome by grief just before being hit by a truck, and at the end of the story, when Pierre's blindness is revealed.

Results for the other story are very similar (Figures 5 and 6). The imagery and emotional response ratings for both the English 'Two Were Left' and the French 'Deux qui restaient' indicate a peak at paragraph 11, when the suffering dog fearfully approaches Noni, who is agonizing over the prospect of striking his faithful friend dead in order to survive. Emotional responses remain high and peak again at paragraph 16 for the French version of the story and at paragraph 17 for the English version; it is at this point in the story that the bond between the boy and his dog proves so strong that neither can kill the other. That is, paragraphs 11 through 17 describe the events that convey the central conflict in the story and are therefore highly emotionally evocative. They closely replicate the rating patterns for 'Two Were Left' in the original study. Also as in the original study, the 
FIGURE 6

'Deux qui restaient' : Imagery and affect.

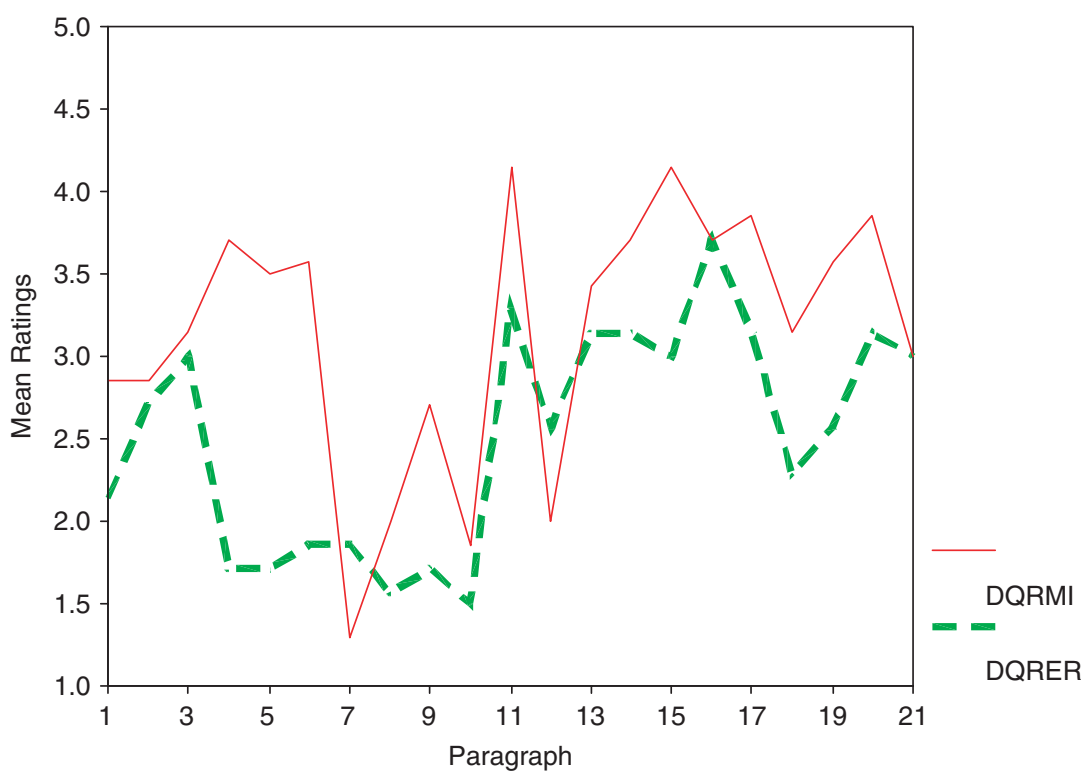

final peak in both imagery and emotional ratings for both English and French versions occurs at end of the story, with the revelation that the gleaming object that has attracted the pilot's attention is the knife Noni forged to kill the dog but flung aside instead.

In order to investigate the degree of agreement between raters, alpha reliability coefficients for the imagery and emotion ratings were computed for each version of each story. The resulting coefficients ranged from 0.87 to 0.96 . Full results appear in Table 2 .

Correlations were computed to determine whether significant relationships existed between the ratings for imagery and emotional response for each story. As in the original study, partial correlations controlling for paragraph length in words were also computed for the ratings for each story and for both stories combined in each language, since longer paragraphs containing more language could possibly evoke more images or emotional responses. Removing the effect of paragraph length in words controls for any such effect. Ratings for paragraphs of both stories were combined to look objectively at the strength of the imagery and affect relationship across a larger set of paragraphs than either story provided. Correlations may differ when 
TABLE 2

Alpha reliability coefficients for agreement across raters

\begin{tabular}{lll}
\hline Story & Imagery & Affect \\
\hline 'A Secret for Two' & 0.94 & 0.96 \\
'Un secret pour deux' & 0.96 & 0.87 \\
'Two Were Left' & 0.90 & 0.89 \\
'Deux qui restaient' & 0.87 & 0.94 \\
\hline
\end{tabular}

TABLE 3

Correlations of paragraph ratings for the imagery and affect

\begin{tabular}{|c|c|c|}
\hline Story or story combination & Simple & Partial $^{\mathrm{a}}$ \\
\hline 'A Secret for Two'/'Two Were Left'combined & $0.44^{* * *}$ & $0.57^{* * *}$ \\
\hline \multicolumn{3}{|l|}{$N=51$ paragraphs } \\
\hline 'Un secret pour deux’/'Deux qui restaient' combined & $0.52^{* * *}$ & $0.68^{* * *}$ \\
\hline \multicolumn{3}{|l|}{$N=51$ paragraphs } \\
\hline 'A Secret forTwo' & $0.37^{*}$ & $0.64^{* * *}$ \\
\hline \multicolumn{3}{|l|}{$N=30$ paragraphs } \\
\hline 'Un secret pour deux' & $0.51^{* *}$ & $0.76^{* * *}$ \\
\hline \multicolumn{3}{|l|}{$N=30$ paragraphs } \\
\hline 'Two Were Left' & $0.63^{* *}$ & $0.71^{* * *}$ \\
\hline \multicolumn{3}{|l|}{$N=21$ paragraphs } \\
\hline 'Deux qui restaient' & $0.58^{* *}$ & $0.55^{*}$ \\
\hline \multicolumn{3}{|l|}{$N=21$ paragraphs } \\
\hline $\begin{array}{l}\text { a Controlling for paragraph length. } \\
{ }^{*} p<0.05 \\
{ }_{* *}^{*} p<0.01 \\
{ }^{* * *} \quad p<0.001\end{array}$ & & \\
\hline
\end{tabular}

data are treated simply as an extended set of paragraphs rather than as two stories, each with its own plot constraints. The simple and partial correlations and their significance levels appear in Table 3. All correlations were statistically significant. Simple correlations ranged from 0.37 to 0.63 , and partial correlations controlling for paragraph length ranged from 0.55 to 0.76 , very similar to the original study.

Correlations were also computed to examine whether significant relationships existed between the imagery and emotion ratings obtained for each language version of the same story and across both stories in both languages. These correlations are shown in Table 4. All correlations were statistically significant, ranging from 0.59 to 0.87 , very similar to the original study. 
TABLE 4

Correlations of paragraph ratings between English and French story versions

\begin{tabular}{lll}
\hline English/French story title & Imagery & Affect \\
\hline 'A Secret for Two' and 'Two Were Left'combined / & $0.59^{* *}$ & $0.79^{* *}$ \\
'Un secret pour deux' and 'Deux qui restaient'combined & & \\
'A Secret for Two'/'Un secret pour deux' & $0.66^{* *}$ & $0.87^{* *}$ \\
'Two Were Left'/'Deux qui restaient & $0.81^{* *}$ & $0.69^{* *}$ \\
\hline$* * \quad p<0.01$ & &
\end{tabular}

We statistically tested the differences in the partial correlation coefficients (controlling for paragraph length) using the Fisher's $z$ test for differences in the correlation coefficient between independent samples. There was no significant difference $(p<0.05)$ in the partial correlation controlling for paragraph length between imagery and affect for the English version of 'A Secret for Two' and the French version 'Un secret pour deux.' Similarly, there was no significant difference $(p<0.05)$ between the partial correlation controlling for paragraph length between imagery and affect for the English version 'Two Were Left' and the French version 'Deux qui restaient.' Nor did we find a significant difference $(p<0.05)$ between the partial correlation controlling for paragraph length for the two stories combined (51 paragraphs) in English and the two stories combined in French.

\section{Reading times}

The mean reading time for 'A Secret for Two' was 7.23 minutes $(S D=1.59)$; the mean reading time for the French version, 'Un secret pour deux,' was 8.92 minutes $(S D=2.07)$. It took the immersion students in the present study approximately $23 \%$ more time to read the French version. The mean reading time for 'Two Were Left' was 3.17 minutes $(S D=0.58)$; the mean reading time for 'Deux qui restaient' was 4.84 minutes $(S D=1.68)$. The immersion students thus took approximately 53\% more time to read the French version. The proportional reading times are greater for the L2 but considerably less than those found by Steffensen et al. (1999).

\section{Qualitative reports}

The two paragraphs in each language version of each story that had the highest mean ratings for imagery and emotional response were 
identified, and students were asked to describe in their own words what images or emotions were evoked when they read these paragraphs. In 'A Secret for Two,' paragraphs 18 and 24 ranked the highest for mental imagery, both with an average rating of 4.57. In paragraph 18, the author describes the steely cold morning as Jacques, the foreman, waits to impart sad news to Pierre. In paragraph 24, the foreman stops to evaluate the grief in Pierre's eyes. For the same story, the highest mean ratings for emotion were for paragraphs 29 (4.43) and 30 (4.29). These concluding paragraphs reveal that Pierre has been blind for five years, implying that his ability to carry out his day-to-day work depended on the trust established between him and his horse. For the French version, 'Un secret pour deux,' the highest average ratings for mental imagery were for paragraph 24 (4.5) and paragraph 14 (4.17); in paragraph 14, the author recounts the company president's inspection of the morning deliveries. Paragraph 29 ranked highest for emotion, with an average rating of 4.67, and paragraphs 19, 26 , and 30 ranked second, with a mean rating of 4.33 . For comparison to the English version, paragraph 30 was selected for reporting.

For 'Two Were Left,' the highest-ranking paragraphs for mental imagery were paragraphs 11 and 19, with average ratings of 4.33 and 4.17 respectively. In paragraph 11, Noni is poised to kill his dog; paragraph 19 describes the scene in which the pilot spies something glinting and the possibility of life below. Paragraphs 11 and 17 ranked highest for emotion, with an average rating of 4.00. In paragraph 17, Noni and Nimuk reconcile themselves to their fate, for neither can betray the other. For the French 'Deux qui restaient,' paragraph 11 again ranked first for mental imagery, with an average rating of 4.33, followed by paragraph 19, with an average rating of 4.17. Average emotional response ratings for 'Deux qui restaient' ranked paragraphs 16 and 11 highest at 3.71 and 3.29 respectively. In paragraph 16, Nimuk licks Noni's face, and the reader gets the sense that the dog cannot hurt Noni any more than Noni could harm Nimuk.

\section{Imagery}

Students reporting on mental imagery wrote longer reports than those reporting on emotion. On average, students wrote approximately 39 words in two to three sentences to describe the mental images formed in response to the paragraphs. The length of reports of mental imagery ranged from three words to 101; students usually wrote their longest response to the first paragraph appearing in their packages. 
Reports of mental imagery are dominated by visual detail, including an average of 1.5 sentences of visual description. For example, in response to paragraph 24 in 'A Secret for Two,' one student wrote,

I imagine a poor homeless man bundled up in torn winter wear and the first thing you see on him is a big bulky hat. With the last few sentences, I just picture these big gray, dead, eyes.

Notably, the descriptions often go beyond the text description, as students drew on personal experience to construct images. For example, in response to paragraph 18 in 'A Secret for Two,' in which the author describes the luminous qualities of a wintry morning, one student reported,

When I read this paragraph, I pictured myself waking up in the morning and walking to the bus. It's always early so it's dark and there's a cold morning breeze...

In response to paragraph 19 in 'Two Were Left,' one student was able to imaginatively project his previous flying experience to put himself in the place of the pilot flying over the tundra:

I know from experience what it's like flying over essentially wasteland and then seeing something out of the ordinary. You just have to check it out! So I can relate to what the pilot felt.

Other students made associative links to events outside the story. In response to paragraph 11 of 'Two Were Left,' one student commented,

My first reaction was the image of dogs that were rescued from puppy mills. I could also picture both Nimuk and Noni suffering physically and mentally with the problem they faced and I could imagine what it felt like when Noni saw the dog's eyes.

Many of the reports of mental imagery include emotional response. In the above reports, one student conveys the excitement associated with seeing something out of the ordinary against the vast wasteland; another attempts to convey the pain and suffering endured by the dog and the boy. The students' reports indicate a particular tendency to invest emotional content in descriptions of images of characters. 
Consider the following response to paragraph 24 of 'A Secret for Two,' in which Pierre is met with sad news:

You can picture the way Pierre's face looked when told of his beloved horse. Pierre would be standing out in the cold with Jacques with his hat pulled over his eyes with this extremely lost look on his face.... It's easy to picture the look of sorrow and loss since it happens to everyone.

Similarly, students responding to the same paragraph from the French translation, 'Un secret pour deux,' included emotional content in their mental imagery reports:

L'image que j'ai dans ma tête est très claire. Je peux voir le chapeau lourd et je peux voir le regard triste dans les yeux de Pierre. Aussi, je peux même ressentir le vent froid.... Je peux ressentir la tristesse [de] Pierre [à ce moment].

[The image that I have in my head is very clear. I can see the heavy hat and I can see the sad look in Pierre's eyes. Also, I can even feel the cold wind.... I can feel Pierre's sadness at this moment.]

Reports of mental imagery in response to stories read in French were only slightly shorter in length (averaging 36 words per report) than reports given in response to the same stories read in English (averaging 41 words per report). The type of visual descriptions and characterizations of emotional states were consistent across both languages:

Quand j'ai lu l'histoire [«Deux qui restaient»] pour la première fois, j'ai noté les images dans ma tête. Dans ce paragraphe, je vois le chien qui s'approche Noni. J'imagine Noni, froid, peureux, et désespéré.

[When I read the story for the first time, I noted the images in my head. In this paragraph, I see the dog approaching Noni. I imagine Noni, cold, fearful, and desperate.]

Imagery descriptions often led to inferences about the characters' thoughts and feelings. The same reader who described the 'extremely lost look' on Pierre's face continues:

Pierre had loved the horse so very much that it's as if a piece of him had died also.... Pierre's so lost without his horse it's as if he has no reason to go on living.

(C) 2008 The Canadian Modern Language Review/La Revue canadienne des langues vivantes, 64, 3 (March/mars), 399-428 
In response to paragraph 11 of 'Deux qui restaient,' another student inferred the following:

In this paragraph, you can picture the poor, suffering dog approaching his owner unaware of the intentions of Noni. You can also see the pain that the deed is causing Noni as his plan to kill the dog goes around in his head. When Noni looks into the dog's eyes, he feels sorry for the dog and wants to put Nimuk out of pain.

In summary, imagery reports are mainly characterized by visual detail and often include emotional content. Students frequently made associative links to personal experience and events outside the story to create mental images and to empathize with characters. Reports of mental imagery often include readers' inferences about the thoughts and feelings that motivate the characters' actions.

\section{Affect}

Students reporting on emotion wrote approximately 32 words in two sentences to express what feelings came to mind when they read the two highest-ranked paragraphs for each story. Reports of emotion range from eight to 107 words. There was very little difference in average length of reports of emotional response between the English and French versions of the stories; students wrote only slightly more in response to the French versions (33 words vs. 31 words). Like their classmates who reported on mental imagery, students wrote their longest reports of emotional response to the first paragraphs appearing in their packages. For 'A Secret for Two,' the highest average ratings for emotion were obtained for the concluding paragraphs, 29 and 30, which relate the tragic death of Pierre and the news of his blindness. Overwhelmingly, students' statements about their own emotional states characterize these reports. In response to paragraph 11 in 'Two Were Left,' one student commented,

I'm an animal lover. I was emotionally affected because I hate to hear about animals suffering. It's just a discomforting thought and I wouldn't wish death or pain upon any living creature.

Again, students projected their personal experiences onto the story in reporting their emotional responses to it. In the following example, a student associates the bond between Nimuk and 
Noni, shown in paragraph 17 of 'Two Were Left,' with her professed love for her cat:

This paragraph is so happy, it makes me feel like crying. My cat knows when I am sad and scared just like the dog knew Noni was. My cat will always purr and cuddle with me. Noni and his dog and my cat and I both share the same friendship.

In addition to statements describing the reader's emotions, these reports often include statements that interpret the emotional state of the characters. For example, in this report a student uses the words 'shock' and 'disgust' to characterize the feelings of the foreman, Jacques, and the ambulance doctor in 'A Secret for Two':

This paragraph was the surprise climax of the story. I could clearly see the look of shock on Jacques' face when the driver [doctor] told him that the man was blind. It also filled me with a sense of amazement and awe to know that the man had been blind for five years and was still able to hide it from his employer... I could also read the disgust the ambulance doctor had for those brief moments when he had to explain to the employer that a man under his own care had been blind for five years and he had no knowledge of it.

The student's recognition that this paragraph is 'the surprise climax of the story' suggests that readers were aware of a connection between their emotional responses and their comprehension of text structure. Similarly, another student remarked in response to paragraph 11 in 'Two Were Left,' where Noni is about to strike his dog, 'First I felt anxiety because it seems like the paragraph is building you up for something exciting that's going to happen.' In this respect, this qualitative report confirms the quantitative findings, which show that patterns of affective response mirror the rising and falling action of the story.

Reports of emotional response to stories read in French are similar in type and length to those written in response to the same stories in English. They include both first-person and third-person statements to express personal feelings, describe a character or situation, or report inferences and personal associations. In response to paragraph 29 of 'Un secret pour deux,' a student included what she inferred was a theme emerging from the story ('Everyone needs a friend to come to when needing help.') Also, just as other students declared their love for animals in response to the stories read in English, reading in her 
L2 did not preclude this reader from associating her own affection for horses with the relationship between Pierre and Joseph:

This makes me feel strong. The blind man was able to deliver milk everyday with his horse even though he was blind. Everyone needs a friend to come to when needing help. This story touches my heart because I have a love for horses. It's also sad that this man had to go through the last five years of his life blind.

In summary, readers reporting emotional response often used a combination of first- and third-person statements to describe their personal feelings, to interpret the feelings of the characters, or to characterize a situation in the story. Except for the minimal differences in average length, there appear to be no distinguishing qualitative differences in reported affective response between stories read in English and stories read in French. Reading in an L2 did not prevent a number of students from making associative links to personal experience and events outside of the text.

\section{Discussion}

In the study reported here, we investigated the extent to which the linguistic demands of reading in an L2 might compromise a reader's capacity to form non-verbal representations and compared the results with the findings of other studies of imagery and affective response. The ratings and reports on the English versions of the stories in this study closely replicate those produced in an English-only study (Sadoski et al., 1988). The only previous study to use this methodology with L2 learners was that of Steffensen et al. (1999); in that study, imagery and affect were found to be fundamental aspects of L2 reading in narrative text about a train trip. In this section, after discussing some similarities and differences between the present study and that of Steffensen et al., we discuss the implications of the findings for theory and practice.

The differences in average reading times would indicate that the participants in the Steffensen et al. (1999) study read their L2, English, with considerably less fluency than the participants in the present study read their L2, French. In the former study, it took participants two and a half to three times as long to read the text in their L2; participants in our study took only $23 \%$ and $53 \%$ longer to read the texts in their L2. The L2 experience of the anglophone high school French immersion students in the present study likely differed in 
many ways from that of the Chinese undergraduate students studying English as a second language who participated in Steffensen et al.'s study.

Another difference between studies relates to the participants' ability to comprehend and respond to the selected texts in their L2. Chinese students reading in English wrote fewer reports of imagery and emotional response than those responding to the same text in Chinese. Given the findings of the present study, in which students' reports of imagery and affect were similar, in terms of content and length, whether they had read the text in English or in French, it would appear that (1) bilingual readers exhibit the ability to form and use verbal and non-verbal representations across languages, generally supporting the linguistic interdependence principle (Cummins, 1979; Cummins \& Swain, 1986; Genesee, 1987; Krashen \& Biber, 1988); and (2) the language threshold hypothesis (Clarke, 1980) is also supported, since it appears that, as bilingual readers progress in their ability to comprehend and decode text in their L2, reports of imagery and affect become closer in kind and number to those reported in response to reading the same text in their L1.

Nevertheless, one cannot completely discount the idea that language and culture constitute a particular world-view. L2 learning takes place in a specific milieu, making generalizations across contexts difficult. Our use of translations is somewhat legitimized by the context of the study. Besides the fact that the stories selected for the present study are set in the far north and in Montreal, their plot structure and the style of linguistic expression used establish them as representative of texts typically encountered in both French and English classrooms in Canadian schools. French translations of children's and young-adult literature originally published for an English-speaking market are commonplace in Canadian French immersion classrooms; such texts range from picture-book favourites by Eric Carle, Rosemary Wells, and Arnold Lobel to novels such as the popular Harry Potter series and Anne of Green Gables. Translations even extend to incorporate the formulaic reading supplied by the Goosebumps and Junie B. Jones series. The choice to use French translations of the English stories was based primarily on the assumption that they would yield the same number of opportunities to form non-verbal representations and that translations are not incongruent to the daily context in which the students read in their L2. The similarities among the reports in response to texts read in both English and French may be due in part to the fact that these students constitute a particular interpretive community (Fish, 1980). 
In the present study, readers are likely to have shared the story authors' mainly Western European perspective on Inuit life and on the life of working-class French Canadians in urban Montreal. Moreover, that interpretive community likely extends to encompass many of the social and cultural characteristics of the participants in the original study (Sadoski et al., 1988), conducted in the United States.

The selection used with the Chinese/English bilingual readers in Steffensen et al.'s (1999) study, however, had to be adapted to account for cultural and linguistic differences across languages, including cultural judgements about the semantic value of specific words and expressions as well as the difficulties inherent in translating a text written in Chinese logographs to English alphabetic writing. At one point, Steffensen et al. acknowledge that the first translation of the text was done with an explicit understanding that the audience consisted of Chinese-speaking students of English as a second language; as a result, it used bland, general terms that made the text more accessible to its audience but sacrificed the more vivid language of the original Chinese. The necessity for a series of back-translations aimed at correcting these problems is evidence of the difficulty of trying to capture the world-view implicit in language itself. If, as Lakoff and Johnson (1999) suggest, language is largely metaphorical and metaphors arise through concrete experience, then language constitutes a living record of a people's social and cultural history. The more languages and cultures differ, the more something is lost in translation, and the socioculturally positioned reader might be expected to respond accordingly.

\section{Implications for theory and practice}

The foregoing discussion implies that current theories of bilingual response to text may need elaboration and development. Language and culture may be inherently linked in such a way that the principles of linguistic interdependence have limitations that need to be addressed. The bilingual extension of DCT (Paivio, 1986; Paivio \& Desrochers, 1980) provides one possible basis for such development. The example used earlier, of the English word bread and its French translation, pain, can serve as an illustration here. In dual-coding terms, bilingual verbal systems are assumed to be connected to the non-verbal system, so that they can share common images or be connected to different ones, depending on the acquisition contexts of the two languages. For some individuals, the common images might predominate, so that bread and pain will evoke images of the same kind 
of bread. For other individuals with different cultural experiences, the independent connections might predominate, resulting in images of different kinds of bread for the two words. Such responses would depend on the cultural and educational contexts in which the L2 was learned. This simple example could be extended to include culturally relevant images and emotional responses to literary texts, encompassing principles of linguistic interdependence.

In the present study, there was a high degree of agreement among raters for imagery and affect for stories read in both languages, and the qualitative reports show consistency in terms of the length and type of reports across languages. However, there was still considerable evidence that the experiential uniqueness of individual readers contributed to the arousal of imagery and affect. This was most often recorded in the associative connections made to individual experiences in statements such as 'I pictured myself waking up in the morning and walking to the bus,' 'I know from experience what it's like flying over essentially wasteland and then seeing something out of the ordinary,' and 'My cat knows when I am sad and scared just like the dog knew Noni was.' In some cases, lack of experience may have limited the formation of non-verbal representations, as in '... but I don't understand how the air was like iced wine.' In another example, a student's faith in an afterlife is implicit in his summation of his emotional response to the conclusion of 'A Secret for Two': 'I' $\mathrm{m}$ sad that he was blind and that he was hit by a truck, but happy because he and his horse get to meet again.' Such experience can be personal, cultural, and even spiritual.

Recent advances in neurobiology aimed at establishing a link between sensory perception and the triggering of emotions and mental images may also shed new light on the findings of the numerous studies that have demonstrated a positive relationship between imagery and affect in reading. In the present study, reports of both imagery and emotional response were often characterized by the reader's capacity for empathy - the ability to imagine oneself in the place of another, as in 'I can feel Pierre's sadness at this moment' and 'It's easy to picture the look of sorrow and loss since it happens to everyone.' Krasny (2007) cites Damasio (1994, 1999, 2003) and others (Dewey, 1934/1987; Fesmire, 1999; Turner, 1996) to argue that our ability to project one life story upon another to achieve feelings of empathy derives from our capacity for imaginative reconfiguration and recombination of parts of our sensory experience stored in our memory. For Damasio, non-verbal representations in the form of emotions and mental imagery are not merely connected but are, in 
fact, part of the same neurobiological phenomenon, in which an emotionally competent stimulus triggers a change in body structures. These changes are mapped by the body and stored in the form of images, visual and otherwise. In the case of narrative reading, the words on the page constitute an emotionally competent stimulus that triggers nonverbal images to accompany the verbal representations. Damasio's 'feeling brain' is based on the premise that our ability to perceive objects and events, both external and internal, requires nonverbal images and that these non-verbal images are the core of our consciousness. Such theoretical extensions could be productive in accounting for the phenomenon of empathy so characteristic of the aesthetic response to literature documented in this study and establishing the formation of imagery and affect as indicators of readers' engagement. Continuing research might also investigate the relationship between bilingual readers' ability to form non-verbal representations and the degree to which $\mathrm{L} 2$ learners attain balance and fluency. Such studies would have to address the present difficulties in assessing bilingual proficiency (Hakuta, Ferdman, \& Diaz, 1987; Haritos \& Nelson, 2001).

Within the reading field, there has been a recurring call for a more complete theory of comprehension (Snow, 2002) and a better understanding of the role of affect (Kress, 2004). Emotional responses and the formation of images are generally considered first-person phenomena and are not presently captured by standardized measures of reading comprehension. In an era of accountability, in which instruction is increasingly directed at achievement on such measures, the growing body of research demonstrating that the evocation of affect and mental imagery can actually enhance the comprehension and recall of texts has been largely ignored. The recognition that readers access both verbal and non-verbal imagery in negotiating texts may incite us to seek instructional strategies that exploit these nonverbal aspects of comprehension with L2 learners who possess limited vocabulary and linguistic knowledge.

Within the reading field, the formation of mental imagery is a welldocumented strategy that has been shown to help students predict (Gambrell, 1982), recall, and comprehend both literary and nonliterary texts (Gambrell \& Jawitz, 1993; Pressley, 1976; Sadoski \& Paivio, 2001, 2004; Sadoski et al., 1988, 2000). While even senior-level immersion students are not balanced bilinguals, the majority of content-area (mathematics, science, social studies) materials published for use by students at all levels are direct translations of English texts. Within the immersion setting, encouraging students to stop 
periodically to image, independently or through small-group activities, may help them negotiate more complex and dense French translations of English textbooks. In addition to scaffolding their understanding, asking students to describe what they see, hear, smell, taste, and feel through think-alouds may also help expose semantic gaps and allow teachers to make more qualitative assessments of students' comprehension of both literary and non-literary texts.

Further implications for language instruction in secondary schools would include learning second languages in culturally relevant, concrete contexts rather than by linguistic translation alone. Little research exists on the effects of L2 instructional practices in responding to literature, but one study with elementary school children aged 8 to 11 exposed French children in a weekly English immersion class and German children in a daily bilingual English class to a Roald Dahl children's story and its filmed version in English (Garcon, 2001). The film likely evoked imagery and affective responses that contributed to the children's overall comprehension of the story. The children also participated in various collaborative activities, such as making story predictions, retelling, matching written sentences with story pictures, completing sentences, building word webs, and writing subsequent paragraphs. Qualitative analysis indicated that the children's responses equalled or surpassed adult interpretations and that the children dealt with unknown vocabulary and long text passages with surprising ease. Students' involvement, enjoyment, and motivation were noted.

Much experimental literature favours an experience-based immersion approach to general L2 proficiency. In a review of studies of learning contexts in French and Spanish second language acquisition, Collentine and Freed (2004) determined that, interestingly, intensive domestic immersion programs were as beneficial as, or more beneficial than, study-abroad programs in most aspects of oral language fluency. Perhaps the positive effects of language concreteness are enhanced within experientially familiar contexts and may help form the nonverbal basis for comprehending the language as well. More research on L2 learning and curriculum theory is needed (Cummins, 1999), and a growing knowledge of embodied cognition and the structure and function of imagery and affect may further establish the critical role of concrete contexts in L2 comprehension.

Karen A. Krasny is an Assistant Professor in the Faculty of Education at York University. Her current research interests are in the areas of literary theory and reader response, adolescent and children's literature, theoretical models of 
reading, embodied cognition, and curriculum theory. Her recent work appears in the Journal of Curriculum Studies, Review of Educational Research, and Curriculum Inquiry.

Mark Sadoski is a Professor and Distinguished Research Fellow in the College of Education and Human Development at Texas A\&M University. He holds joint appointments in the Department of Teaching, Learning, and Culture; the Department of Educational Psychology; and the Office of Educational Development, Texas A\&M College of Medicine. His current research interests are cognition in literacy and curriculum and instruction in literacy.

\section{References}

Alderson, J. (1984). Reading: A reading problem or a language problem? In J. Alderson \& A. Urquhart (Eds.), Reading in a foreign language (pp. 1-24). Harlow, UK: Longman.

Anderson, R., Reynolds, R., Schallert, D., \& Goetz, E. (1977). Frameworks for comprehending discourse. American Educational Research Journal, 14, 367-381.

Berger, E. (Ed.). (1958). The best short shorts. New York: Scholastic.

Bernhardt, E., \& Kamil, M. (1995). Interpreting relationships between L1 and L2 reading: Consolidating the linguistic threshold and the linguistic interdependence hypotheses. Applied Linguistics, 16, 15-34.

Bossers, B. (1991). On thresholds, ceilings and short-circuits: The relation between L1 reading, L2 reading and L2 knowledge. Revue de l'AILA, 8, 45-61.

Brisbois, J. (1995). Connections between first- and second-language reading. Journal of Reading Behavior, 27, 565-584.

Carrell, P. (1991). Second language reading: Reading ability or language proficiency? Applied Linguistics, 12, 159-179.

Clarke, M. (1980). The short-circuit hypothesis of ESL reading, or when language competence interferes with reading performance. Modern Language Journal, 64, 203-209.

Collentine, J., \& Freed, B.F. (2004). Learning context and its effect on second language acquisition: Introduction. Studies in Second Language Acquisition, 26, 153-171.

Cummins, J. (1979). Linguistic interdependence and the educational development of bilingual children. Review of Educational Research, 49, 222-251.

Cummins, J. (1999). Alternate paradigms in bilingual education research: Does theory have a place? Educational Researcher, 28, 26-32. 
Cummins, J., \& Swain, M. (1986). Bilingualism and education. London: Longman.

Damasio, A. (1994). Descartes' error: Emotion, reason, and the human brain. New York: Putnam.

Damasio, A. (1999). The feeling of what happens: Body and emotion in the making of consciousness. New York: Harcourt.

Damasio, A. (2003). Looking for Spinoza: Joy, sorrow, and the feeling brain. New York: Harcourt.

Dewey, J. (1987). Art as experience (J. Boydston, Ed.). The later works of John Dewey, 1925-1953. Vol. 10. Carbondale: Southern Illinois University Press. (Original work published 1934)

Fecteau, M. (1999). First- and second-language reading comprehension of literary texts. Modern Language Journal, 83, 475-493.

Fesmire, S. (1999). Morality as art: Dewey, metaphor, and moral imagination. Transactions of the Charles S. Peirce Society, 35, 527-550.

Fish, S. (1980). Is there a text in this class? The authority of interpretive communities. Cambridge, MA: Harvard University Press.

Gambrell, L. (1982). Induced mental imagery and the text prediction performance of first and third graders. In J. Niles \& L. Harris (Eds.), New inquiries in reading research and instruction (pp. 131-135). Rochester, NY:

National Reading Conference.

Gambrell, L., \& Bales, R. (1986). Mental imagery and the comprehension monitoring performance of fourth- and fifth-grade poor readers. Reading Research Quarterly, 21, 454-464.

Gambrell, L., \& Jawitz, P. (1993). Mental imagery, text illustrations, and children's story comprehension and recall. Reading Research Quarterly, 28, 264-276.

Garcon, J. (2001). Novels and films in the elementary school foreign language class. Journal of the Imagination in Language Learning, 6, 46-53.

Genesee, F. (1987). Learning through two languages: Studies of immersion and bilingual education. Rowley, MA: Newbury House.

Goetz, E.T., \& Sadoski, M. (1996). Imaginative processes in literary comprehension. In R.J. Kreuz \& M.S. MacNealy (Eds.), Empirical approaches to literature and aesthetics (pp. 221-240). Norwood, NJ: Ablex.

Goetz, E., Schallert, D., Reynolds, R., \& Radin, D. (1983). Reading in perspective: What real cops and pretend burglars look for in a story. Journal of Educational Psychology, 75, 500-510.

Hacquebord, H. (1989). Teksthegrip van Turkse en Nederlandse leerlingen in het voorigezet onderwijs [Text comprehension of Turkish and Dutch students in secondary education]. Dordrecht, The Netherlands: Foris.

Hakuta, K., Ferdman, B., \& Diaz, R. (1987). Bilingualism and cognitive development: Three perspectives. In S. Rosenberg (Ed.), Advances in applied

(C) 2008 The Canadian Modern Language Review/La Revue canadienne des langues vivantes, 64, 3 (March/mars), 399-428 
psycholinguistics: Reading, writing, and language learning (Vol. 2, pp. 284-319). Cambridge: Cambridge University Press.

Haritos, C., \& Nelson, K. (2001). Bilingual memory: The interaction of language and thought. Bilingual Research Journal, 24, 417-438.

Johnson, M. (1993). Moral imagination: Implications of cognitive science for ethics. Chicago: University of Chicago Press.

Kintsch, W., \& Greene, E. (1978). The role of culture-specific schemata in the comprehension and recall of stories. Discourse Processes, 1, 1-13.

Kosslyn, S (1994). Image and brain: A resolution to the imagery debate. Cambridge, MA: MIT Press.

Krashen, S., \& Biber, D. (1988). On course: Bilingual education's success in California. Sacramento: California Association for Bilingual Education.

Krasny, K. (2007). Seeking the affective and the imaginative in the act of reading: Embodied consciousness and the evolution of the moral self. In D. Vokey (Ed.), Philosophy of Education 2006 (pp. 429-437). Normal, IL: Philosophy of Education Society.

Kress, G. (2004, December). Cultural technologies of representation and communication: Reading and writing in the era of the new screens. Distinguished International Scholar Address, 2004 National Reading Conference, San Antonio, TX.

Lakoff, G., \& Johnson, M. (1999). Philosophy in the flesh: The embodied mind and its challenge to Western thought. New York: Basic Books.

Lee, J.-L., \& Lemmonnier-Schallert, D. (1997). The relative contribution of L2 language proficiency and L1 reading ability to L2 reading performance: A test of the threshold hypothesis in an EFL context. TESOL Quarterly, 31, 713-739.

Long, S.A., Winograd, P.A., \& Bridge, C.A. (1989). The effects of reader and text characteristics on reports of imagery during and after reading. Reading Research Quarterly, 24, 353-372.

Nussbaum, M. (2001). Upheavals of thought: The intelligence of emotions. Cambridge: Cambridge University Press.

Paivio, A. (1971). Images and verbal processes. New York: Holt, Rinehart, \& Winston.

Paivio, A. (1986). Mental representations: A dual coding approach. New York: Oxford University Press.

Paivio, A. (1991). Dual coding theory: Retrospect and current status. Canadian Journal of Psychology, 45, 255-287.

Paivio, A. (2007). Mind and its evolution: A dual coding theoretical approach. Mahwah, NJ: Lawrence Erlbaum.

Paivio, A., \& Desrochers, A. (1980). A dual-coding approach in bilingual memory. Canadian Journal of Psychology, 34, 255-287. 
Pichette, F. (1995). Lecture en langue seconde. In J. Audette, M.-A. Bélanger, A. Bourcier, I. Dion, P. Larrivée, J. Nicole, F. Pichette, \& E. Rosales (Eds.), Actes des IX journées de linguistique (pp. 105-110). Sainte-Foy, QC: Presses de l'Université Laval.

Pritchard, R. (1990). The effects of cultural schemata on reading processing strategies. Reading Research Quarterly, 25, 273-295.

Pressley, G. (1976). Mental imagery helps eight-year-olds remember what they read. Journal of Educational Psychology, 68, 355-359.

Report of the Royal Commission on Bilingualism and Biculturalism. (1970).

Ottawa: Queen's Printer.

Reynolds, R., Taylor, M., Steffensen, M., Shirey, L., \& Anderson, R. (1982). Cultural schemata and reading comprehension. Reading Research Quarterly, 17, 353-366.

Roller, C. (1988). Transfer of cognitive academic competence and L2 reading in a rural Zimbabwean primary school. TESOL Quarterly, 22, 303-328.

Rosenblatt, L.M. (1994). The transactional theory of reading and writing. In R.B. Ruddell, M.R. Ruddell, \& H. Singer (Eds.), Theoretical models and processes of reading (4th ed., pp. 1057-1092). Newark, DE: International Reading Association.

Sadoski, M., \& Paivio, A. (2001). Imagery and text: A dual coding theory of reading and writing. Mahwah, NJ: Lawrence Erlbaum.

Sadoski, M., \& Paivio, A. (2004). A dual coding theoretical model of reading. In R.B. Ruddell \& N.J. Unrau (Eds.), Theoretical models and processes of reading (5th ed., pp. 1329-1362). Newark, DE: International Reading Association.

Sadoski, M., Goetz, E.T., \& Kangiser, S. (1988). Imagination in story response: Relationships between imagery, affect, and structural importance.

Reading Research Quarterly, 23, 320-336.

Sadoski, M., Goetz, E.T., \& Rodriguez, M. (2000). Engaging texts: Effects of concreteness on comprehensibility, interest, and recall in four text types. Journal of Educational Psychology, 92, 85-95.

Snow, C. (2002). Reading for understanding: Toward an RED program in reading comprehension. Santa Monica, CA: RAND.

Steffensen, M., Goetz, E., \& Cheng, X. (1999). A cross-linguistic perspective on imagery and affect in reading: Dual coding in Chinese and English. Journal of Literacy Research, 31, 293-319.

Taillefer, G. (1996). L2 reading ability: Further insight into the short-circuit hypothesis. Modern Language Journal, 80, 461-477.

Turner, M. (1996). The literary mind. New York: Oxford University Press.

Wagner, D., Spratt, J., \& Ezzaki, A. (1989). Does learning to read in a second language always put the child at a disadvantage? Some counterevidence from Morocco. Applied Psycholinguistics, 10, 31-48. 
Copyright of Canadian Modern Language Review is the property of University of Toronto Press and its content may not be copied or emailed to multiple sites or posted to a listserv without the copyright holder's express written permission. However, users may print, download, or email articles for individual use. 